for British scientists. These, and many other issues he raised, such as increasing scientists' interactions with industry, commerce and the media, and resisting the politicization of climate-change research, are relevant throughout the world and not just in Britain.

All the more reason not to misinterpret Nurse's insistence on a separation of science and politics: as he put it, first we need the science, then the politics. What Nurse rightly warned against is the intrusion of ideology into the interpretation and acceptance of scientific knowledge as, for example, in the Soviet Union's support of the anti-Mendelian biology of Trofim Lysenko. Given recent accounts of political interference in climate research in the United States (N. Oreskes and E. M. Conway Nature 465,$686 ; 2010)$, this is a timely reminder.

But it is easy to render this equation too simplistically. For example, Nurse also cited the rejection by Adolf Hitler of Albert Einstein's relativistic physics as 'Jewish physics'. But that is not quite how it was. 'Jewish physics' was a straw man invented by the anti-Semitic and proNazi physicists Johannes Stark and Philipp Lenard, partly because of professional jealousies and grudges. The Nazi leaders were, however, largely indifferent to what looked like an academic squabble, and in the end lost interest in Stark and Lenard's risible 'Aryan physics' because they needed a physics that actually worked.

That is one reason to be sceptical of the common claim, repeated by Nurse, that science can flourish only in a free society. Historians of science in Nazi Germany such as Kristie Macrakis (in her book Surviving the Swastika) have challenged this assertion, which is not made true simply because we would like it to be so. Authoritarian regimes are perfectly capable of putting pragmatism before ideology. The scientific process itself is not impeded by state control in China - quite the contrary - and the old canard that Chinese science lacks innovation and daring is now transparently nonsense. During the cold war, some Soviet science was vibrant and bold. Even the most notorious example of state repression of science - the trial of Galileo - is apt to be portrayed too simplistically as a conflict of faith and reason rather than a collision of personalities and circumstances (none of which exonerates Galileo's scandalous persecution).

There is a more compelling lesson to be drawn from Nazi Germany that bears on Nurse's themes: although political (and religious) ideol-
"The practice of science is inherently political." ogy has no place in deciding scientific questions, the practice of science is inherently political. In that sense, science can never come before politics. Scientists everywhere enter into a social contract, not least because they are not their own paymasters. Much, if not most, scientific research has social and political implications, often broadly visible from the outset. In times of crisis (like the present), scientists must respond intellectually and professionally to the challenges facing society, and not think that safeguarding their funding is enough.

The consequences of imagining that science can remain aloof from politics became acutely apparent in Germany in 1933, when the consensus view that politics was, as Heisenberg put it, an unseemly "money business" meant that most scientists saw no reason to mount concerted resistance to the expulsion of Jewish colleagues - regarded as a political rather than a moral matter. This 'apolitical' attitude can now be seen as a convenient myth that led to acquiescence in the Nazi regime and made it easy for German scientists to be manipulated. It would be naive to imagine that only totalitarianism could create such a situation.

The rare and most prominent exception to apolitical behaviour was Einstein, whose outspokenness dismayed even his principled friends the German physicists Max Planck and Max von Laue. "I do not share your view that the scientist should observe silence in political matters," he told them. "Does not such restraint signify a lack of responsibility?" There was no hint of such a lack in Nurse's talk. But we must take care to distinguish the political immunity of scientific reasoning from the political dimensions and obligations of doing science.

\section{Gold in the text?}

\section{Publishers and scientists should do more to foster the mining of research literature by computer.}

$\mathrm{W}$ hether from the petabytes of data produced by the Large Hadron Collider, or the hundreds of millions of bases in the human genome, much scientific analysis nowadays relies on computers to pull out meaning from swathes of data. But one vast store of information, the research literature, has so far seemed immune to computer analysis. By and large, articles exist only in formats designed for humans to read — such as this paragraph.

Text-mining aims to break down this barrier. Using natural-languageprocessing concepts honed over the past 30 years, computer programs are starting to pull out information from plain text, including patents and research articles. Right now, the software requires highly skilled operators, but in the next decade it might transform the way scientists read the literature. Text-miners hope to make scientific discoveries by scouring hundreds of research papers for associations and connections (such as between drugs and side effects, or genes and disease pathways) that humans reading each paper individually might not notice.

The promise is yet to be backed up with concrete examples of scientific success - although in the pharmaceutical industry, text-mining companies are already working with researchers to speed up drug discovery. But academics are struggling to even run experiments because publishing licences do not let them text-mine research papers, and publishers are slow to respond to text-mining requests. Fed up after two years of negotiations, one team of researchers is launching a public website to log publishers' responses (see page 134).
There is no doubt that a completely open research literature would make it easier to demonstrate how such machine-reading can lead to scientific discovery. But the question is how to make progress today, when much research lies behind subscription firewalls and even 'open' content does not always come with a text-mining licence (including $83 \%$ of the 'free' research in the PubMedCentral online archive).

Publishers should agree that scientists who have already paid for access to research papers may text-mine content at no extra cost and publish their findings - as long as their doing so does not breach the original firewall. Publishers can have no claim on the data in articles, only on the way in which the articles have been edited and formatted. They should make their text-mining policies clear and consider following the example of the journal Heredity, which says it is "seeking to encourage text-mining experiments". (Its publisher, Nature Publishing Group, which also publishes this journal, says that it does not charge subscribers to mine content, subject to contract.)

On the other hand, text-miners need to make a better case for their technology. They say they are in a catch-22 situation - how can they demonstrate the benefits if they aren't allowed to run experiments on the literature? Instead, they text-mine abstracts, usually by picking out key words - a pale shadow of what full-text-mining might offer. Casey Bergman at the University of Manchester, UK, is chronicling projects that have tried to text-mine the available PubMedCentral content (see go.nature.com/2pqp8g) and finds very few examples - suggesting that text-miners are reluctant even to mine the corpus of free content.

Publishers point out that they receive few text-mining requests, so the field can't be very hot. So unless text-miners start to make full use
DNATURE.COM To comment online, click on Editorials at: go.nature.com/xhunqv of the content that is available, and request more access to published content - while always being clear about how their project will benefit science - the unsatisfactory impasse will continue. 